\title{
IQTISHODUNA
}

\section{Optimizing The Mawah Concept for The Economy of The Aceh Community}

\author{
Mukhtasar1, Angga Syahputra ${ }^{2}$ \\ 1,2 Departement Islamic Banking, Faculty of Ekonomi dan Bisnis Islam, Institut Agama Islam \\ Negeri Lhokseumawe, Jl. Medan-Banda Aceh No. 1 Alue Awe Kec. Muara Dua Lhokseumawe, \\ 24352, Provinsi Aceh, Indonesia \\ E-mail: ${ }^{1}$ mukhtasar@iainlhokseumawe.ac.id ${ }^{2}$ anggasyahputra@iainlhokseumawe.ac.id
}

\begin{abstract}
Islam and Aceh are inseparable like two sides of a coin. The Serambi Makkah Country in the daily activities of its people is closely related to islamic sharia, including muamalah activities. Long before the existence of Islamic financial institutions in Indonesia, the people of Aceh had implemented cooperation in the field of muamalah as well as the mudharabah concept in Islamic financial institutions, known as mawah. Mawah is a concept of cooperation between capital owners and managers with a profit-sharing system. But the concept of mawah is still limited to cooperation in agriculture and animal husbandry, so it is necessary to development efforts in other spheres to be able to sustain the economy of the people of Aceh, as Denmark successfully developed this concept. This study uses qualitative methods by researching natural object conditions and is supported by a literature review. The results of the study revealed the need for government intervention in developing this concept in order to be optimal in developing the economy of the people of Aceh.
\end{abstract}

Keywords: mawah, economic optimization, Aceh community.

Abstrak: Islam dan Aceh adalah hal yang tidak terpisahkan seperti dua sisi mata uang. Negeri Serambi Mekkah ini dalam keseharian aktifitas masyarakatnya berkaitan erat dengan syariah Islam, termasuk kegiatan muamalah. Jauh sebelum adanya lembaga keuangan syariah di Indonesia, masyarakat Aceh sudah menerapkan kerjasama di bidang muamalah seperti halnya konsep mudharabah pada lembaga keuangan syariah, yang dikenal dengan istilah mawah. Mawah merupakan sebuah konsep kerjasama antara pemilik modal dengan pengelola dengan sistem bagi hasil. Namun konsep mawah masih terbatas pada kerjasama di bidang pertanian dan peternakan, sehingga perlu dilakukan upaya pengembangan pada lingkup lain agar mampu menopang perekonomian masyarakat Aceh, sebagaimana Denmark sukses mengembangkan konsep ini. Penelitian ini menggunakan metode kualitatif dengan melakukan penelitian pada kondisi objek yang alamiah, serta didukung dengan kajian literatur. Hasil penelitian mengungkapkan perlu campur tangan pemerintah dalam mengembangkan konsep ini agar dapat optimal dalam mengembangkan perekonomian masyarakat Aceh.

Kata kunci: mawah; optimalisasi ekonomi; masyarakat aceh.

\section{Introduction}

Aceh or also often spelled as Acheh, Acheen, Atjeh and several other names following the
Encyclopedia Britannica (1998) is an area now known as Aceh Province. Aceh is a truly special and special area. This province which is located 
where the profits between the capital owner and the capital manager are divided according to the agreement at the beginning.

In practice in Acehnese society, mawah is still limited to the scope of agriculture and animal husbandry, does not reach other aspects which if developed will stimulate the community's economy. The concept is still very traditional in its application, raises several problems, so that its existence is not optimal. For this reason, further studies need to be done to maximize the tradition of mawah into a solution to optimize the economy, especially for the people of Aceh.

\section{Literature Review}

The concept of mawah is currently used by the people of Aceh so that their assets are not neglected and the economy continues to run smoothly. The productivity step through the mawah concept is mostly done by the Acehnese people because it is an investment channel for those who have excess funds. ${ }^{4}$ Unfortunately, the practice is not accompanied by better concepts and supervision from the government.

Syamsuddin ${ }^{5}$ in his previous research revealed that the practice of mawah can be developed into a broader capital concept for the people of Aceh if it is carried out with a good concept as Denmark has

${ }^{4}$ Fitri Maghfirah, Eksistensi Konsep Mawah Sebagai Penguat Ekonomi Masyarakat Aceh, (Thesis, UIN Sunan Kalijaga, 2020), 5.

5Syamsuddin, "Peran Konsep Mawah Sebagai Edukasi Permodalan Masyarakat Aceh", NEGOTIUM, Jurnal Ilmu Administrasi Bisnis, Vol. 1, No. 1, (2018), 44. applied it. Denmark formed an institution that supervised this activity and successfully developed it. This certainly can be used as an example for the Government of Aceh to optimize the concept of mawah.

\section{Methodology}

The method used in this study is a qualitative method. According to Bogdan and Taylor (1996) ${ }^{6}$ qualitative methods are research procedures that produce descriptive data in the form of written or oral words from people and observable behavior. Thus this approach is directed at the setting and individual holistically (whole).

Thus, the qualitative method is a research method used to examine natural object conditions where the researcher is a key instrument, the data analyst is inductive, with the results of research that emphasize more on meaning than generalization.

Data collection techniques used in this study were library research. Literature research aims to obtain secondary data conducted by collecting data sourced from the literature, in the form of legislation, books, or literature, scientific journals, magazines, articles, and the web relating to the problem under study and the writings scientifically related to the problem to be studied.

\section{Results and Discussion}

\footnotetext{
${ }^{6}$ Bogdan \& Taylor, dikutip tidak langsung oleh Lexy J. Moeleng, Metodologi Penelitian Kualitatif, (Bandung: PT. Remaja Rosda Karya, Ed. 7, 1996), 3.
} 


\section{Mawah Concept}

Mawah is an economic practice that has existed since the sultanate of Aceh, namely the 16th century. ${ }^{7}$ The practice of mawah is very popular in Acehnese society where its implementation is based on the principle of profit sharing between capital owners and managers. Mawah is a mechanism whereby an asset owner surrenders the management rights of the asset to another person with an agreed sharing of results.

In the life of the people of Aceh, the practice of mawah has a significant role in the economy, the availability of sufficient grain, the economic assistance of the poor, can open jobs, vacant land can be tilled, and increased productivity of rice and grain so that no more land and rice fields displaced.

This mawah practice is in line with the Hadith of the Rasulullah Saw. which reads: "From Jabir ra. said, said the Rasulullah Saw.: "Whoever has a piece of land, he should plant it. If he is unable or unable to plant it, then it should be left to someone else (to be planted) and don't rent it out" (HR. Muslim).

Another basis for the people of Aceh to do this practice in accordance with the Alquran, which means: "O you who believe, do not take (eat) the property of your fellow humans in a false way, except by

\footnotetext{
${ }^{7}$ Nazamuddin, Economic Modernization and Its Influence On The Social System In Aceh, in Graf A; Aceh History, Politics and Culture, (Singapore: Institute of Southeast Asian Studies, 2013), 92.
}

commercial means, voluntarily escorted you."8

The role and concept of mawah in Aceh can improve the quality of life of people in rural areas and people with social welfare problems, with the aim of: 9

1. Increased handling of the poor population and services for people with social welfare;

2. Increasing the quality of life and protection of women and children;

3. Increased empowerment of rural communities through the agricultural sector.

During the monetary crisis in 1998, the people of Aceh, especially those living in rural areas, were barely familiar with and felt its effects. In its implementation, the mawah system is widely practiced in agriculture and animal husbandry. ${ }^{10}$ In the field of agriculture, mawah objects are rice fields, fields and so on. Rice fields in Aceh are called Blang or bueng. Blang is a rice field complex that is located close together, for example including a gampong (village) and can also be said to be a piece of land or open fields. While the bueng is a terraced rice field made on a hillside or mountain. ${ }^{11}$

8QS. An-Nisa': 29
9Eko Dikdoyo, Pemberdayaan
Masyarakat Daerah Tertinggal, (Bandung: PT.
Cita Pustaka, 2002), h. 25
10Azharsyah Ibrahim, Praktik
Ekonomi Masyarakat Aceh Dalam Konteks
Ekonomi Islam: Kajian Terhadap Sistem Mawah
dan Gala, (Malaysia: Proceeding of the Aceh
Development International Conference,
IIUM, 2012), 444.
11Snouck Hurgronje, The Achehnese,
terj. Ng. Singarimbun, S. Maimoen, Kustiniyati


For animal husbandry, mawah objects are bulls, buffaloes, goats, and so on. The results shared depend on the agreement of the two parties. Agreements are generally based on management costs, both direct and indirect. ${ }^{12}$

In agriculture, the most important thing in profit sharing is the initial agreement, namely the willingness of both parties to prevent future disputes. Some of these mawah practices are even intended to help the economically weak group by the more established groups, so that the benefits for land owners are not so important. 13

Mawah activities have existed to date because of the easy agreement process based on mutual trust between the owner and manager and has a high economic value if successful in management for parties who do not have capital, especially in the management of livestock such as cattle, buffalo, goats and other livestock. ${ }^{14}$

Mawah can be said as an investment language. The intended investment here is giving up capital to the person who is in business, so that he gets a percentage of the profits. This form of business involves two parties, those who have

Mochtar, (Jakarta: Yayasan Soko Guru, 1985), 292.

${ }^{12}$ Azharsyah Ibrahim, Praktik, p. 444

${ }^{13}$ Departemen Pendidikan dan Kebudayaan, Pola Penguasaan, Pemilikan dan Penggunaan Tanah Secara Tradisional Provinsi Daerah Istimewa Aceh, (Banda Aceh: Pusat Penelitian Sejarah dan Budaya, 1984), 67.

${ }^{14}$ Muslim Ibrahim, Rapat Paripurna ke-IV Majelis Permusyawaratan Aceh Masa Kerja 2016, http://mpu.acehprov.go.id, accessed Oktober 25 2019 capital but cannot do business and those who are good at business but do not have capital, so that both parties complement each other. ${ }^{15}$ The practice of mawah is generally carried out by people who are economically weak, but this mawah activity is not necessarily done. Some of the perpetrators work as civil servants, traders, pedicab drivers, but generally farmers and ranchers. ${ }^{16}$ This practice is still commonly found in gampong in Aceh Province to this day.

Mawah in the AcehIndonesian dictionary is written with the term "maw'aih" which means a method of sharing the results of doing rice fields by using one's own tools, raising one's livestock by earning half of his income. ${ }^{17}$

According to Hurgronje $(1985)^{18}$, mawah in Acehnese language is synonymous with meudua profit, which is profit divided in half equally. In their implementation they surrendered their land based on the mawah contract (peumawah), did not intervene again until the harvest. Then he will attend himself or his

${ }^{15}$ Abdullah al-Mushlih dan Shalah Ash-Shawi, Fikih Ekonomi Keuangan Islam, cet. 7, (Jakarta: Darul Haq, 2004), 168.

16Furqan \& Hidayan S, "Pemberdayaan Masyarakat Melalui Tradisi Mawah (Studi Kasus Pemeliharaan Ternak Sapi Di Desa Mibo Kecamatan Banda Raya Banda Aceh)", Al-Idarah, Vol. 2, No. 1 (Januari - Juni 2018), 28.

${ }^{17} \mathrm{Abu}$ Bakar et. al, Kamus Bahasa Aceh-Indonesia 2 cet. 2, (Jakarta: Balai Pustaka, 2008), 582.

18Snouck Hurgronje, The Achehnese, p. 326 
representative to count the rice and put half of it aside.

Historically, the development of mawah practices in the agricultural sector due to rice farming for the people of Aceh is a virtue. ${ }^{19}$

A local motto states "kaya meueh hana meusape, kaya pade meusampurna" (rich in gold is nothing, rich in rice is perfect). This motto describes someone must have an abundant availability of rice as a form of perfect wealth. ${ }^{20}$

The practice of mawah has a significant share in the economic activities of the gampong community in general such as the availability of sufficient grain, poor economic assistance for the poor, employment opportunities, people who have land can be tilled, and increased productivity of rice and paddy so that no more land and rice fields abandoned. It's just that so far the local government has paid less attention to mawah practices, so that in practice they have constraints and have an impact on the results that are not maximized in mawah practices. ${ }^{21}$

${ }^{19}$ Sri Sudiarti, Pangeran Harahap, \& Nanda Safarida, "Mawah \& Cater Di Aceh Studi Peningkatan Kesejahteraan Masyarakat di Ulim -Kab. Pidie Jaya", AlMuamalat Jurnal Hukum Ekonomi Syariah, Vol 3, No. 1, (2017), 136.

${ }^{20}$ Jongejans J, Negeri Dan Rakyat Aceh Dahulu dan Sekarang, terj. Rusdi Sufi, (Banda Aceh: Pemerintah Provinsi NAD Badan Arsip dan Perpustakaan, 2008), 189.

${ }^{21}$ Abdurrahman, "Praktek Mawah Melalui Mudharabah Dalam Masyarakat Aceh", Premise Law Jurnal, Vol. 11, No. 1 (2015), 6.
Examining history and the concept of mawah initially only limited to cooperation in agriculture and animal husbandry, but this concept can actually be expanded into other economic fields, such as trade and other sectors. This is in accordance with the understanding of mawah published by the Aceh Ulama Consultative Assembly, that mawah is aqad between the owner of the property and the manager whose results are divided based on agreement. 22

If examined more deeply, the practice of this mawah concept is the same as mudharabah transactions conducted by Islamic banks in financing customers. Mudharabah is a form of cooperation in which the owner of capital/assets entrusts his property to be managed by someone else with profit divided between the two based on agreed terms, while the loss will be borne by the capital owner. ${ }^{23}$ The loss is only borne by the owner of the capital because the manager is considered to have experienced a loss of time and energy, provided that the loss is not caused by negligence of the manager. ${ }^{24}$

In mudharabah practice, someone who has capital, for example agricultural capital in the

22Majelis Permusyawaratan Ulama Aceh, Fatwa MPU Aceh Nomor 4 Tahun 2016 Tentang Mawah, Banda Aceh, 2016.

${ }^{23}$ Rachmat Syafei, Figh Muamalah Untuk IAIN, STAIN, PTAIS dan Umum, (Bandung: Pustaka Setia, 2001), 224.

${ }^{24}$ Aries Mufti dan M. Syakir Sula, Amanah Bagi Bangsa: Konsep Sistem Ekonomi Syariah, (Jakarta: MES dan Bank Indonesia, 2007), 64 . 
form of land, will be entrusted to others to work on it, where the results will be shared.

The practice of mudharabah is already well-known among the Jahiliyah Arabs, especially with the Quraysh. In general, commerce was the work of the Arabs at that time, where the owner of the property handed over his wealth to the manager to be managed in order to gain profit. This was also done by trade caravans led by Abu Sufyan, mostly with the mudharabah system.

Islam views muamalah activities as part of human life that cannot be separated from the Alquran and Sunnah. ${ }^{25}$ Mudharabah cooperation with the mawah form is also practiced by the Rasulullah Saw. both before and after he became a Prophet and Rasul, for example when he sold merchandise belonging to Khadija Ra. ${ }^{26}$ In this case, Khadijah acted as shahibul mal, while the Rasulullah Saw. acting as executor (mudharib). ${ }^{27}$ Just like the mudharabah concept, mawah practices are also required to honestly report the results obtained from their arable land, because usually landowners do not directly monitor the results of the cultivated land, in Islamic banking this is referred to as trust financing

${ }^{25}$ Angga Syahputra, "Etika Berbisnis Dalam Pandangan Islam", Jurnal At-Tijarah: Jurnal Penelitian Keuangan dan Perbankan Syariah, Vol. 1, No. 1, (Juni 2019), h. 23.

26Zaki Fuad Chalil, Horizon Ekonomi Syariah: Pemenuhan Kebutuhan dan Distribusi Pendapatan, (Banda Aceh: Ar-Raniry Press, 2008), 190.

${ }^{27}$ Adiwarman A. Karim, Bank Islam: Analisis Figh dan Keuangan, (Jakarta: Raja Grafindo Persada, 2004), 192. or trust investment. The elements of usury, gharar, tadlis are also not found in the practice of mawah applied by the people of Aceh.

\section{Mawah Optimization}

The practice of mawah if applied in a broader form, can sustain the Acehnese economy towards a better direction. This concept also has priority in the principles of Islamic economics, namely sincerity, ukhuwah, work and productivity. If it is developed, work productivity will achieve three goals, meet the necessities of life (isyba'), achieve a reasonable profit (irbah) and create a prosperous social environment, especially empowerment that is not able to naturally (al-i'mar).28

The concept of ownership of property in Islam that the absolute ownership of everything on earth is Allah. human ownership is only relative. For this reason, this concept needs to be preserved and developed in order to provide assistance to the weak and move the wheels of the economy (Syahputra, 2018)..$^{29}$

With capital of the mawah tradition which has been traditionally carried out by the Acehnese people, the Aceh Government should be able to develop this concept for the improvement of the Acehnese

${ }^{28}$ Fauzi Saleh, Mawah (Opini di Harian Serambi Indonesia), Edisi 20 Mei 2011.

${ }^{29}$ Angga Syahputra, "Etika Bisnis Dalam Islam: Suatu Jalan Keseimbangan Dalam Berbisnis", Jurnal At-Tanmiyah, Vol. 1, No. 1, (2018), 66. 
economy. The Government of Aceh can facilitate the operation of this system by reflecting on the British state as the center of Islamic finance in the world or to Malaysia who is the foremost in Islamic Finance in Asia.

In line with mudharabah, a word derived from the word dharb, which etymologically means traveling or walking. The Alquran does not directly indicate the meaning of mudharabah, but implicitly, the basic word dha-ra-ba which is the basic word mudharabah is mentioned in the Alquran fiftyeight times. ${ }^{30}$

According to the Mazhab Hanafi, mudharabah is a form of agreement in conducting joint ventures to obtain profits with capital from one party and work (business) from another party.

Meanwhile, according to the Mazhab Maliki, mudharabah is the transfer of money upfront by the owner of the capital in the amount of money specified to someone who will run the business with that money accompanied by a portion of the rewards and profits of his business. According to Mazhab Syafii, the mudharabah definition is the owner of the capital giving up an amount of money to the entrepreneur to be carried out in a trading business with profits being the joint property of the two. Meanwhile, according to the Mazhab Hambali, mudharabah is the

\footnotetext{
${ }^{30}$ Abdullah Saeed, Bank Islam dan Bunga: Studi Kritis dan Interpretasi Kontemporer tentang Riba dan Bunga, (Yogyakarta: Pustaka Pelajar, 2008), 91.
}

surrender of goods or the like in clear and certain amounts to the person who commits them by obtaining a certain portion of his profits. ${ }^{31}$

The mudharabah pillars are as follows:

1. Contracting parties, capital owners (shahibul mal) and capital managers (mudharib);

2. Capital;

3. Business undertaken;

4. Advantages;

5. Ijab and qabul.

While the mudharabah requirements:

1. The parties making the contract are required to have the ability and competence in law (mukallaf);

2. Capital is a sum of money and/or assets given by the owner of funds to mudharib for business purposes with the following conditions:

a. The amount and type of capital must be known;

b.Capital can be in the form of money or goods being valued. If capital is given in the form of an asset, the asset must be valued at the time of the contract; and

c. Capital cannot be in the form of receivables.

3. The contract is written down, through correspondence or using modern methods of communication.

4. Benefits, on condition:

a. Must be for both parties;

b.Profits are divided proportionally, written in the

${ }^{31}$ Muhammad, Etika Bisnis Islam, (Yogyakarta: AMP YKPN, 2004), 82-83 
contract according to the agreement;

c. Shahibul mal bears all losses resulting from mudharabah, while managers may not incur any loss, except as a result of intentional, negligence, or breach of agreement (Majelis Ulama Indonesia, 2000). 32

From the understanding, pillars and conditions described above, the mawah can be pronounced with mudarabah. It's just to make optimization, the Government of Aceh needs to improve practices so that the role of the mawah can be optimal to sustain the economy of the people of Aceh. Some things that are important for improvement are as follows:

1. The Importance of Recording Transactions

The practice of mawah which has so far only been limited to an oral agreement between shahibul mal and mudharib on the basis of trust. This is certainly prone to cause conflicts behind the day. As the requirements in the mudharabah order and the Alquran instructions to Surah Al-Baqarah: 282 , this activity must be written in an agreement concerning the profit sharing, agreement between the two parties, and the period of cooperation.

2. Establishment of Mawah Institution

This institution is aimed at controlling the mawah activities carried out by the community,

${ }^{32}$ Fatwa DSN MUI Nomor 07/DSNMUI/IV/2000 conducting data collection, and providing solutions if in practice mawah has obstacles. This institution is also expected to manage this very traditional activity, so that it can produce optimal results. In agricultural practices, for example, farmers often complain about the difficulty of obtaining funds for management of rice fields, not to mention the costs when plowing rice fields are also relatively very high. ${ }^{33}$ Finally, this institution is also expected to be the first level of mediator in the event of a dispute between shahibul mal and mudharib.

3. Widening in Other Sectors

So far, the practice of mawah is still limited to the agriculture and livestock sectors. To optimize the economy with existing institutions, it is hoped that mawah practices can be developed to other sectors, such as the industrial and trade sectors. The agricultural sector currently contributes to the Indonesian economy in the first quarter of 2019 by $12.65 \%$, if it is developed into other sectors, it can boost economic growth in other fields. In the first quarter of 2019, the trade sector contributed $12.20 \%$ and $20.07 \%$ was still contributed

\footnotetext{
${ }^{33}$ Nelly \& Rahmi, "Strategi Pengentasan Kemiskinan Berbasis Kearifan Lokal, Masyarakat Aceh Melalui Praktek Adat Mawah (Bagi Hasil Usaha) di Kecamatan Kuta Baro", Prosiding Seminar Nasional Universitas Serambi Mekkah, Vol. 1, No. 1, (Oktober 2017), 345-353.
} 
by the industrial sector (Badan Pusat Statistik, 2019). ${ }^{34}$

4. Maximization of Arbitration Institutions

As a cultural custom product, the involvement of traditional institutions in mawah cooperation becomes a necessity. In the Aceh community there are several traditional institutions that live and develop, namely: Tuha Puet, Imeum Meunasah, Keujruen Blang, Panglima Laot, Elder Seuneubok, Haria Peukan, Syahbanda and so on. In the case of agriculture, Keujruen Blang has the duty to lead and regulate paddy activities, especially if disputes occur..$^{35}$

As in the attachment of the National Sharia Council Indonesian Ulama Council related to the dispute between shahibul mal and mudharib, it can be done through consensus agreement, if it is not achieved then it can be done through dispute resolution institutions based on sharia according to applicable laws and regulations.

In this case, if the adat institution is not able to be the mediator of the dispute, the Sharia Court must play an active role in resolving the dispute. The Sharia Court in Aceh was formed after the promulgation of Law No. 18 of 2001 which was subsequently

\footnotetext{
${ }^{34}$ Badan Pusat Statistik, Aceh Dalam Angka, www.bps.go.id, accessed October 30th 2019.

${ }^{35}$ Edy Mulyana, Aceh Menembus Batas, (Banda Aceh: Badan Perpustakaan NAD, 2007), 111.
}

replaced by Law No. 11 of 2006 concerning the Government of Aceh. Article 128 paragraph (4) gives authority to the Sharia Court in the field of family, civil and criminal law, both relating to the provisions of material law and formal law (the law of the event).

5. Socialization

The word socialization has the meaning of the learning process of a community member to recognize and appreciate the culture of the community in his environment. Besides that it can also mean efforts to socialize something, so that it becomes known, understood, internalized by the community; correctional facilities. ${ }^{36}$

The practice of mawah and the expansion of its practice can only work well if the Government and the Regional Apparatus conduct socialization to the community. At present there are various kinds of media as socialization, such as mass media, electronic media, and social media. The government can also widely disseminate this practice through recitation, imeum masjid, and preachers to reach various levels of society.

\section{Conclusion}

Mawah is an economic practice that has existed since the sultanate of Aceh, namely the 16th century. The practice of mawah is

${ }^{36}$ Kamus Besar Bahasa Indonesia, http://kbbi.web.id, accessed October $30^{\text {th }}$ 2019 
very popular in Acehnese society where its implementation is based on the principle of profit sharing between capital owners and managers. Mawah is a mechanism whereby an asset owner surrenders the management rights of the asset to another person with an agreed sharing of results.

If examined more deeply, the practice of this mawah concept is the same as mudharabah transactions conducted by Islamic banks in financing customers. Mudharabah is a form of cooperation in which the owner of capital/assets entrusts his property to be managed by someone else with profits divided between the two based on agreed terms, while the loss will be borne by the capital owner. The loss is only borne by the owner of the capital because the manager is considered to have experienced a loss of time and energy, provided that the loss is not caused by negligence of the manager.

The practice of mawah if applied in a broader form, can support the Acehnese economy in a better direction. This concept also has priority in the principles of Islamic economics, namely sincerity, ukhuwah, work and productivity. If it is developed, its work productivity will reach three goals, fulfill life's needs (isyba'), achieve reasonable profit (irbah) and create environmental prosperity both socially, especially the empowerment of the incapable and natural (al-i'mar).

To optimize the role of mawah to sustain and improve the economy of the Acehnese people, the government needs to support and take steps, such as educating about the importance of recording transactions in mawah activities, establishing institutions that oversee mawah activities, widening in other sectors, maximizing arbitration institutions, and outreach to the wider community. 


\section{REFRENCES}

Abdurrahman. "Praktek Mawah Melalui Mudharabah Dalam Masyarakat Aceh", Premise Law Jurnal, Vol. 11, No.1 (2015).

Al-Mushlih, Abdullah \& Ash-Shawi, Shalah. 2004. Fikih Ekonomi Keuangan Islam, cet. 7. Jakarta: Darul Haq.

Badan Pusat Statistik. "Aceh Dalam Angka", www.bps.go.id, accessed October 30th 2019

Bakar, Abu et al. 2008. Kamus Bahasa Aceh-Indonesia, ed. 2, cet. 2. Jakarta: Balai Pustaka.

Bank Indonesia. 2019. Laporan Perekonomian Provinsi Aceh Mei 2019. Jakarta: Bank Indonesia.

Bogdan dan Taylor. 1996. Metodologi Penelitian Kualitatif, cet. Ke 7. Bandung: PT. Remaja Rosda Karya.

Chalil, Fuad, Zaki. 2008. Horizon Ekonomi Syariah: Pemenuhan Kebutuhan dan Distribusi Pendapatan. Banda Aceh: ArRaniry Press.

Departemen Pendidikan dan Kebudayaan. 1984. Pola Penguasaan, Pemilikan dan Penggunaan Tanah Secara Tradisional Provinsi Daerah Istimewa Aceh. Banda Aceh: Pusat Penelitian Sejarah dan Budaya.
Dikdoyo, Eko. 2002. Pemberdayaan Masyarakat Daerah Tertinggal. Bandung: PT. Cita Pustaka.

Furqan \& Hidayan, S. "Pemberdayaan Masyarakat

Melalui Tradisi Mawah (Studi

Kasus Pemeliharaan Ternak Sapi Di Desa Mibo Kecamatan Banda Raya Banda Aceh", AlIdarah, Vol 2, No. 1 (Januari Juni 2018).

Hurgronje, Snouck. 1985. The Achehnese, terj. Ng. Singarimbun, S. Maimoen, Kustiniyati Mochtar. Jakarta: Yayasan Soko Guru.

Ibrahim, Azharsyah. 2012. "Praktik Ekonomi Masyarakat Aceh Dalam Konteks Ekonomi Islam: Kajian Terhadap Sistem Mawah dan Gala". Paper on Proceeding of the Aceh Development International Conference - IIUM, Malaysia.

J. Jongejans. 2008. Negeri dan Rakyat Aceh Dahulu Dan Sekarang, terj. Rusdi Sufi. Banda Aceh: Pemerintah Provinsi NAD Badan Arsip dan Perpustakaan.

Karim, Adiwarman A. 2004. Bank Islam: Analisis Figh dan Keuangan. Jakarta: Raja Grafindo Persada.

Kamus Besar Bahasa Indonesia. http://kbbi.web.id, accessed October 30th 2019 
Maghfirah, Fitri. 2020. Eksistensi Konsep Mawah Sebagai Penguat Ekonomi Masyarakat Aceh. Thesis Universitas Islam Negeri Sunan Kalijaga, Yogyakarta, Indonesia.

Majelis Permusyawaratan Ulama Aceh. 2016. Fatwa MPU Aceh Nomor 4 Tahun 2016 Tentang Mawah.

“Rapat Paripurna ke-IV Majelis Permusyawaratan Aceh Masa Kerja 2016", http://mpu.acehprov.go.id, accessed October 25 2019.

Majelis Ulama Indonesia. 2000. Fatwa DSN MUI Nomor 07/DSN-MUI/IV/2000

Manan, Bagir. 2001. Menyongsong Fajar Otonomi Daerah. Yogyakarta: Pusat Studi Hukum Fakultas Hukum Universitas Islam Indonesia.

Mufti, Aries \& Sula, M. Syakir. 2007. Amanah Bagi Bangsa: Konsep Sistem Ekonomi Syariah. Jakarta: MES dan Bank Indonesia.

Muhammad. 2004. Etika Bisnis Islam. Yogyakarta: AMP YKPN.

Mulyana, Edy. 2007. Aceh Menembus Batas. Banda Aceh: Badan Perpustakaan NAD.

Nazamuddin. 2013. Economic Modernization and Its Influence On The Social System In Aceh, in Graf A; Aceh History, Politics and Culture.
Singapore: Institute of Southeast Asian Studies.

Nelly \& Rahmi. "Strategi Pengentasan Kemiskinan Berbasis Kearifan Lokal, Masyarakat Aceh Melalui Praktek Adat Mawah (Bagi Hasil Usaha) di Kecamatan Kuta Baro" paper pada Prosiding Seminar Nasional Universitas Serambi Mekkah, Vol 1, No. 1, Oktober 2017, Banda Aceh, Aceh.

Saeed, Abdullah. 2008. Bank Islam dan Bunga: Studi Kritis dan Interpretasi Kontemporer tentang Riba dan Bunga. Yogyakarta: Pustaka Pelajar.

Saleh, Fauzi. 2011. Mawah. Opini di Harian Serambi Indonesia,

Ed. 20 Mei 2011.

Sudiarti, Sri., Harahap, Pangeran., \& Safarida, Nanda. "Mawah \&

Cater di Aceh; Studi Peningkatan Kesejahteraan Masyarakat di

Ulim- Kab. Pidie jaya", Al-Muamalat: Jurnal Hukum Ekonomi Syariah

Vol 3, No. 1 (2017).

Syamsuddin. "Peran Konsep Mawah Sebagai Edukasi Permodalan Masyarakat Aceh", NEGOTIUM, Jurnal Ilmu Administrasi Bisnis, Vol. 1, No. 1 (2018).

Syafei, Rachmat. 2001. Figh Muamalah Untuk IAIN, STAIN, PTAIS dan Umum. Bandung: Pustaka Setia.

Syahputra, Angga. "Etika Bisnis Dalam Islam: Suatu Jalan Keseimbangan Dalam 
IQTISHODUNA: Jurnal Ekonomi Islam

Volume 9 Issue 2, October 2020

Berbisnis", Jurnal At-Tanmiyah, Vol.

1, No. 1 (2018).

“Etika Berbisnis Dalam

Pandangan Islam", Jurnal At-

Tijarah: Jurnal Penelitian

Keuangan dan Perbankan

Syariah, Vol. 1, No. 1 (Juni

2019). 